\title{
RELIGIOUS ISSUES IN AMERICAN PUBLIC EDUCATION ${ }^{\dagger}$
}

\author{
HaROLD H. PUNRE*
}

It is hoped that grouping materials as follows will help readers evaluate this article: (I) public and sectarian uses and disposition of property, (II) objections to school regulations, (III) retirement credit for parochial school experience, (IV) released time for religious instruction, (V) public funds for parochial schools, (VI) taking over by churches of public schools and revenues, and (VII) conclusions.

I

\section{Public and Sectartan Uses and Disposition of Property}

Several sectarian and non-school public uses of school property have recently been in dispute.

\section{A. Bible Reading in Public Schools}

Since the United States began developing an extensive public school system, numerous cases have arisen over reading Bible selections at school exercises, and court rulings have varied considerably-even under fairly uniform legal provisions. In 1950, the New Jersey Supreme Court adjudicated the constitutionality of a statute which provided:1 "At least five verses ... from ... the Old Testament shall be read . . . without comment, in each public school classroom ... by the teacher"unless the reading was done at a general assembly. Board regulation permitted a student to be excused from the exercises concerned. Any religious exercise, other than Bible reading and repeating the Lord's Prayer, "in any school receiving . . . moneys appropriated for . . . public schools," was forbidden by statute.

Judge Case upheld the constitutionality of the Bible-reading statute-against charges that it violated the First Amendment to the Federal Constitution which forbids both religion established by law and state interference with free exercise of religion, and violated the Fourteenth Amendment which forbids states to deprive persons of life, liberty, or property without due process of law or to deny them equal protection of the laws. He said the First Amendment did not deny the existence of a Supreme Being; noted recognitions of God in our governmental foundation and practice--the Declaration of Independence, oath of the President and of judges, chaplains in Congress and in the armed forces, and the words "In God We Trust" on coins; and found that because of its antiquity and acceptance by Jews, Roman

fIn I95I the author analyzed the cases, up to that time, on some aspects of this subject. Sce Community Uses of Public Schoor Facilities 35-89 (Columbia University, King's Crown Press, 1951). See also the symposium, Religion and the State, I4 LAw \& CONTEMP. Prob. 1-168 (1949).

- Professor of Education, Alabama Polytechnic Institute.

${ }^{1}$ Doremus v. Board of Education of Hawthorne, 5 N. J. $435,437,75$ A.2d 88o, 881 (Sup. Ct. 1950); N. J. STAT. ANN. \$\$18: 14-77, 14-78 (1940). 
Catholics, and Protestants, the Old Testament when read without comment was not sectarian. Regarding the Lord's Prayer, he cited a Rabbi indicating that it was essentially an old Jewish prayer, "The Kaddish," and held that reciting it in a public school was not religious instruction within the meaning of the Federal Constitution. He thought it important that the statute had been unchallenged for 47 years.

Before the case reached the United States Supreme Court, ${ }^{2}$ plaintiff's daughter graduated from high school, thus changing the basis of the complaint, and a majority of that Court held that a taxpayer's economic interest in preventing Bible reading and prayer was too miscroscopic and diffused to maintain the suit. Justice Douglas, in a dissent concurred in by Justices Reed and Burton, stated that the interest of one taxpayer was no different in character from the interest of all taxpayers, and that this interest justified a decision of the case on its merits.

\section{B. Mandamus to Secure Use of School Auditorium}

Jehovah's Witnesses have recently sought to compel school authorities to permit use of school auditoriums by Witnesses for meetings. A Pennsylvania school board rule $e^{3}$ prohibited the use of school buildings "for any religious or sectarian purpose." The intended use, as stated by Witnesses, was for Bible lectures which would:

Explain from the Scriptures that man's effort to build a better world has failed because of the desire to establish a man-made order based on human wisdom, greed, and selfishness, to rule humanity in place of Almıghtx God's Kingdom, for which Christ Jesus taught all men of good will to pray. Detailed consideration is given to the various prophecies of Holy Writ to prove that the time is near at hand, as foreordained by the Most High God, when Jehovah himself will permanently shake away Satan's domination of this world and its inhabitants and destroy the Devil and his wicked earthly organization, which has for centuries caused human suffering and trouble. The message ... will clearly establish that the only righteous government for suffering humanity is the Kingdom of Almrghty God, under his King, Christ Jesus, which sole everlasting government for the entire earth will establish conditions of peace and plenty and which will also bring everlasting life and perfect health to the willingly obedient persons of every land, kindred and tongue....

A statute authorized the use of school buildings "for social, recreation, and other proper purposes, under such ... regulations as the board may adopt." Plaintiffs contended that the board in permitting various non-school uses had exhausted its discretion in permitting such uses, and urged their proposed use as among "other proper purposes." The court recognized the intended use as sectarian, considered it a matter of board discretion whether any non-school use should be granted, and stated that the exercise of less than full discretionary power could not be challenged unless it was arbitrarily used. The Witnesses showed no auditorium use by other religious groups nor that discretion was otherwise abused. The board's action was upheld.

${ }^{2} 342$ U.S. 429 (1952).

${ }^{3}$ McKnight v. Board of Public Education, 99 Pitsburgh Legal J. 185 , I86-187 (Com. Pl. 1949), affd, 365 Pa. 422, 76 A.2d 207 (1950), appeal dismissed, 341 U.S. 913 (1951). PA. STAT. Ann. tit. 24, \$7-775 (Purdon r950). 
Ohio Witnesses likewise sought permission by mandamus for similar use of a school auditorium. ${ }^{4}$ A statutory provision stipulated:

Upon application of any responsible organization, or of a group of at least seven citizens, all ... schoolhouses ... shall be available ... as social centers for ... entertainment and education ... the discussion of all topics tending to the development of personal character and of civic welfare, and for religious exercises ... the board ... shall . . . permit the use of any schoolhouse ... when not in actual use for school purposes, for ... educational, religious, civic, social or recreational meetings and entertainments, and for ... other purposes [that aid community welfare].

The court found that Witnesses were not a "responsible" group-noting that they refuse to render military or jury service, their teachings are against those of the schools, they call other religions rackets, the proposed meetings were for propaganda, and no member of the group here seeking to use the auditorium was a district resident or taxpayer; and said that a large majority of the district residents requested that the use of the auditorium not be granted. The court considered it the board's duty to determine what auditorium use prejudiced community welfare or interfered with school. In upholding the board's rejection of the Witnesses' demand, the court found no abuse of discretion or interference with constitutional religious liberty. ${ }^{5}$

\section{Distribution of Religious Literature}

A 1952 New Mexico case concerned "distributing" religious literature through public schools. ${ }^{6}$ Presbyterian pamphlets were kept in plain sight of pupils in Anson's school room. He did not hand them to pupils or tell pupils to take or read them, but apparently pupils did so since occasional replenishment was necessary. A statute provided: "No teacher shall use any sectarian or denominational books ... or teach sectarian doctrine in the schools" and indicated penalties for violations. The court followed the Zellers case-discussed subsequently (see note 67 , infra). Uncertainty about the role of Anson and his principal in making the pamphlets available, enabled these persons to escape penalty, but pamphlet distribution had to stop.

In the Tudor case ${ }^{7}$ Gideons applied to the school board for permission to distribute Bibles to pupils. If parents desired their children to have Bibles, as shown by signing a form provided by the school, teachers would give each child a Bible after school hours on a specified day. The board accepted the plan over objections by Catholics and Jews. The court held the Gideon Bible to be sectarian literature,

\footnotetext{
'State ex rel. Greisinger v. Grand Rapids Board of Education, 88 Ohio App. 364, roo N.E.2d 294 (1949), appeal dismissed, I53 Ohio St. 474, 92 N.E.2d 393 (1950), cert. denied, 340 U.S. 820 (1950), rehearing denied, $34 \mathrm{I}$ U.S. 9I7 (r95I). See OHIo Gen. CoDe $\$ 4839-1$, 4839-2 (1945).

"Authority of public officials to decide upon "duly constituted religious bodies" is considered later by Mr. Justice Jackson in his Zorach dissent, note 47 infra.

o Miller v. Cooper, 56 N.M. 355, 244 P.2d 520 (1952). See N. M. Stat. ANn. 555-1102 (1941 Comp.).

${ }^{7}$ Tudor v. Board of Education, $\mathrm{I}_{4}$ N.J. 3r, roo A.2d 857 (Sup. Ct. 1953), cert. denied, 75 Sup. Ct. 25 (1954).
} 
and distributing it through public school machinery to violate the "establishment of religion" clauses of the New Jersey and Federal Constitutions.

\section{Holding Baccalaureate or Graduation Exercises in a Church}

In the Miller case, ${ }^{8}$ baccalaureate services were held in a Baptist Church and graduation exercises in a Presbyterian Church-the only buildings with adequate seating space. It was urged that holding such activities in churches violated the principle of separation of church and state. In upholding the practice, the court said this principle would not prevent holding these programs "in a building where all who desire to attend may be accommodated," and did not fear that those conducting the services would "give offense to anyone attending."

\section{E. Joint School and Church Ownership of Property}

In I892 a Texas church acquired fee simple title to a 3.7 acre tract, ${ }^{9}$ including a small building used primarily for religious purposes but also for secular education. In Igoo a common school district was formed. Thereafter the building was used jointly by church and school without cost to the district. By IgI7 these uses had outgrown the building, and the church sold it for \$100. The proceeds, plus "varying smaller amounts paid out of the maintenance fund of the school district and derived from voluntary contributions by patrons of the church and school," were used to erect a new building on the tract. This building too was used jointly, until the district was merged into the Otto District in I935. After merging, the district made no effort to use the building or remove it from church land. In I945 the church sold the building and the district claimed the proceeds. Statutes regarding title and control of school property were irrelevant, said the court, since there was no evidence that the district constructed the building or had any agreement that it was personalty severable from the land. Whether any I9I7 contributions were made exclusively for either church or district was also irrelevant, since district action in I935 constituted abandonment for school purposes. The building was church property when sold.

\section{F. Sale of School Property to a Church at a Reduced Price}

A majority of the voters in a New York common school district, upon consolidation into a central district, voted to sell their schoolhouse to a church. ${ }^{\mathbf{1 0}}$ At the meeting, the common school electors had an opportunity to vote on number I of the following propositions and on as many others as seemed necessary.

Proposition I was whether the common district should be discontinued, pursuant to Section 1804 of the New York Education Law.

Proposition 2 was whether the common district should sell its existing schoolhouse to Ross Mills Church of God for $\$ 2,000$.

\footnotetext{
${ }^{8}$ Supra note 6, 56 N.M. at 357,244 P.2d at 52 I.

'Evangelical St. John's Church v. Otto Independent School Dist., 203 S.W.2d 299 (Tex. Civ. App. 1947).

${ }^{10}$ Application of Ross, 127 N.Y.S.2d 400, 406-407 (Sup. Ct. I954).
} 
Proposition 3 was whether the common district should sell its existing schoolhouse to Ross Grange No. 305 for $\$ 3,000$.

Proposition 4 was whether or not its existing schoolhouse should be sold at public auction.

Proposition I carried, 33 to 28 . Proposition 2 was then submitted. During debate it was moved that proposition 4 be voted on, but this was ruled out of order. A motion to adjourn met the same fate. A motion followed to change the amount in proposition 2 from $\$ 2,000$ to $\$ 2,500$. This was ruled out of order. Ross made a cash offer of $\$ 4,000$, which was disregarded. A vote on proposition 2 then carried, 32 to 24 . No votes were taken on propositions 3 and 4 .

Section $x 804$ of the New York Education Law provided that the board of a common district

shall not sell or otherwise dispose of property ... except with the approval of a majority of the qualified voters ... present and voting upon the question at a meeting ... duly called. . . . For that purpose the proceeds of such sale ... shall be apportioned among the taxpayers of such existing district.

The statute makes no provision "for the manner or terms of sale," said the court, and confers no power on voters to establish such terms. The court noted that when proposition I passed, the common district was discontinued and its power endedat least temporarily. It then became the duty of the central district board to find a purchaser, acting in the interest of the common district taxpayers and securing the highest possible price-with the proposed method of sale (sealed bid, public auction, or other) within board discretion. Voters of the common district might then approve or reject the proposal. However worthy the motives of the majority in trying to sell the building to the church, observed the court, "they lacked the power to impose their will upon the minority or upon the taxpayers, who have no voice or vote, and whose property they were attempting to give away, in part at least, without their consent."

This holding might have been similar if the beneficiary of a proposed "give away" had been a non-church agency.

II

\section{Objections to School Regulations}

Several recent cases relate to rather generally accepted principles, but belong in a systematic review.

\section{A. Religion and Compulsory School Attendance}

In I953 Turner was fined for violating a California attendance law requiring parents to send their children to public or private school, or to have them taught by a tutor with valid credentials. ${ }^{11}$ Turner insisted that he be permitted to educate his children himself and cited the Pierce $\operatorname{case}^{12}$ as forbidding a state to prescribe the

${ }^{11}$ People v. Turner, 263 P.2d 685, 687-688 (Cal. Super. Ct. 1953).

12 Pierce v. Society of Sisters, 268 U.S. 5 ro (1925). 
manner by which parents educate their children. This case held that attendance requirements might be met by attending private schools, observed the California court, but did not prevent the state from inspecting such schools for acceptability. The California court followed the Hoyt case, ${ }^{13}$ which rejected education by private tutor, quoting as follows:

If the parent undertakes to make use of units of education so small, or facilities of such doubtful quality, that supervision thereof would impose an unreasonable burden upon the state, he offends against the reasonable provisions for schools which can be supervised without unreasonable expense. The state may require, not only that educational facilities be supplied, but also that they be so supplied that the facts in relation thereto can be ascertained, and proper direction thereof maintained, without unreasonable cost to the state. Anything less than this would take from the state all efficient authority to regulate the education of the prospective voting population.

When it was complained that the California statute prescribed training qualifications for tutors and parents but not for teachers in private schools, the court responded:

The most obvious reason for such difference in treatment is ... the difficulty in supervising without unreasonable expense a host of individuals, widely scattered, who might undertake to instruct individual children in their homes as compared with the less difficult and expensive supervision of teachers in organized private schools. Also the legislature might reasonably have concluded that teachers in private schools would be under direct supervision of their school authorities at all times, and that the interests of the persons conducting the same would compel the maintenance of the required standard of instruction by competent instructors for otherwise the school would fail to qualify for the exemption granted thereby, and without pupils it could not continue to exist.

The court added that the state may prescribe both adequate education and the means for achieving it-unless an authoritative federal court rules otherwise.

A Virginia statute ${ }^{\mathbf{1 4}}$ prescribed attendance at a public or private school, or education "by a tutor or teacher of qualification prescribed by the State Board and approved by the division superintendent," and prescribed that tutorial instruction be given on each school day for the number of hours that public school was in session. For religious reasons, parents did not send their children to school but taught them at home. The parents made no attempt to meet certification requirements and admitted instructing the children fewer hours than the statute prescribed. They contended that the statute interfered with their right to rear and educate their children as they saw fit-so long as the children received proper education. In rejecting this contention, the court stated:

The religious beliefs of the defendants ... do not exempt them from complying with the reasonable requirements of Virginia laws. The constitutional protection of religious freedom, while it insures religious equality ... does not provide immunity from compliance with reasonable civil requirements imposed by the State.

\footnotetext{
${ }^{13}$ State v. Hoyt, 84 N.H. 38,4 I, I46 A. 17o, 171 (1929).

14 Rice v. Commonwealth, $x 88$ Va. $224,234,237,49$ S.E.2d $342,347,348$ (r948). VA. CoDE $\$ 22-$ 251 (1950).
} 
The court said that an ignorant parent could not circumvent the law by attempting to educate his children himself:

No amount of religious fervor he may entertain in opposition to adequate instruction should be allowed to work a lifelong injury to his child. Nor should he, for this religious reason, be suffered to inflict another illiterate citizen on his community or his State. It is not and cannot be questioned that the parent should possess some learning and some training in the art of teaching.

When the parents contended that their competence to teach was a question for a jury, the court responded that the evaluation of such competence was a professional task for qualified persons as provided by the State Board of Education-not for a jury of laymen.

\section{B. Regulation of Parochial versus Private Non-sectarian Schools}

A New York statute forbade establishing certain types of schools, except by public authorities or religious groups, unless the school was duly registered. ${ }^{16}$ Packer Collegiate Institute maintained a school of the type concerned but refused to register it. Packer contended that the regulation of such schools was not proper exercise of police power, but the court responded that the legislature might regulate "any business or occupation affected with a public interest" and that education was so affected.

Packer also contended that the statute violated federal and state constitutional provisions by discriminating against private non-sectarian schools in favor of private sectarian schools. In rejecting this contention, the court said:

There is a distinction in fact between sectarian and non-sectarian schools. One is supported by a group commonly considered to be dedicated to the protection of public and private morals. The other may or may not be supported by those who have such a design and interest, but common repute has it that many non-sectarian private schools are operated primarily for profit. The Legislature was not required for regulatory purposes to cast both types of schools in the same mold. An act does not discriminate unconstitutionally against one class simply because it does not embrace all classes, where room for some distinction exists. The Legislature may choose for regulation the class where harmful effects are more apt to exist.

\section{Moslem Religious Holidays}

Bey contended that the Koran made Friday a Moslem holy day and that requiring his children to attend school that day violated his constitutional religious freedom. ${ }^{16}$ However, a statute required children to "attend school continuously through the entire term" but permitted compliance through instruction by a qualified tutor. In the court's judgment, the Koran required saying the creed, saying prayers five times a day, giving alms, observing the feast of Ramadon, and making

${ }^{15}$ Packer Collegiate Institute v. University of State of New York, 273 App. Div. 203, 208-209, 76 N.Y.S.2d 499, 505 (3d Dep't 1948). See N.Y. EDuc. Law \$3210.

${ }^{18}$ Commonwealth v. Bey, 92 Pittsburgh Legal J. 84 (Pa. Com. Pl. 1944). PA. Stat. AnN. tit. 24, \$13-1327 (Purdon, 1950). 
a pilgrimage to Mecca, but neither Moslem principles nor religious freedom was violated by Friday attendance. Even if Bey felt religious scruples about Friday, said the court, his children were entitled to education; he was not legally required to send his children to a public school, but if he chose that method of educating them he would have to obey the laws concerned.

\section{Compulsory Flag Saluting ${ }^{17}$}

Although in 1943 the Supreme Court of the United States held that children could not be compelled to salute and pledge allegiance to the flag under penalty of expulsion from public school, ${ }^{18}$ as was becoming a frequent practice, certain flag cases have since arisen. Most such cases concern Jehovah Witnesses, who regard saluting as idolatry (see Exodus 20:4-5).

Several cases here noted arose in Pennsylvania before 1945 . One case ${ }^{19}$ referred to a 1942 Act of Congress which codified rules and customs regarding flag usage. The court noted that, after describing the method of salute, the act states: "However, civilians will always show full respect for the flag when the pledge is given by merely standing at attention, men removing the headdress." The Nemchik children were dismissed from school for failing to salute, and were encouraged by their mother in not saluting. She protested loyalty to the country, but said that it could not be manifested through flag saluting. When she came before the court for violating the compulsory attendance law, the court held that she was within her rights.

In a 1944 case $^{20}$ the court said that school officials could neither compel children to salute nor expel them for not saluting. As authority, the court quoted Justice Jackson, who spoke for the majority in the 1943 Barnette case: ${ }^{21}$

The right of a State to regulate, for example, a public utility may well include, so far as the due process test is concerned, power to impose all of the restrictions which the legislature may have a "rational basis" for adopting. But freedoms of speech and of press, of assembly, and of worship may not be infringed on such slender grounds. They are susceptible of restriction only to prevent grave and immediate danger to interests which the State may lawfully protect. ...

We think the action of the local authorities in compelling the flag salute and pledge transcends constitutional limitations on their power and invades the sphere of intellect and spirit which it is the purpose of the First Amendment of our Constitution to reserve from all official control.

The foregoing decision controlled another Pennsylvania case. ${ }^{22}$ In a I943 South Dakota case $^{23}$ the court said that, in view of the Barnette decision, school officials

\footnotetext{
${ }^{17}$ Earlier the author reviewed decisions and related materials on this topic: The Flags and the Courts in Free Public Education, 24 J. of ReLIGion II9-I30 (April, I944).

${ }^{18}$ West Virginia State Board of Education v. Barnette, 3x9 U.S. 624 (x943).

${ }^{20}$ Commonwealth v. Nemchik, 36 Luz. Legal Reg. 247, 248 (Pa. Com. Pl., 1942). 56 Stat. 379, I075, 36 U.S.C. $\$ \$ 172-177$ (I942).

${ }^{20}$ Commonwealth v. Conte, I54 Pa. Super. Ir2, II5-II6, 35 A.2d 742, 743 (1944), cert. denied, 323 U.S. 717 (1944).

${ }^{21} 319$ U.S. 624 , at 639,642 .

22 Commonwealth v. Crowley, $x 54$ Pa. Super. Ir6, 35 A.2d 744 (I944).

${ }^{33}$ State v. Davis, 69 S.D. 328, Io N.W.2d 288 (I943).
} 
could neither require a boy to salute, expel him for not saluting, nor convict his parents of violating compulsory attendance laws because of absence resulting from a salute controversy.

The Bortlick children were sent home from school in Pennsylvania for refusing to salute and pledge allegiance. ${ }^{24}$ The court cited pre-Barnette authority for holding that the salute regulation was reasonable, that it in no way interfered with religious freedom, and that Bortlick was violating the compulsory attendance law.

\section{E. Vaccination Required for Admission to School}

Although several years ago the United States Supreme Court held in the Jacobson case $^{25}$ that a state could exclude unvaccinated children from its schools, controversies on the subject continue to arise. Most objections to vaccination are religious. In I95 an Ohio child ${ }^{26}$ was excluded under a board rule prescribing exclusion unless parents offered satisfactory evidence of immunization against smallpox. The parent refused vaccination because medication was contrary to his religion, claimed the rule interfered with constitutional religious liberty, and attempted to force the board to provide other education for his unvaccinated child. The court rejected his arguments.

A statute required children to be vaccinated before they could attend public school in New York City. ${ }^{27}$ A mother, on religious grounds, refused to have her daughter vaccinated. The court said constitutional religious liberty did not protect a person who conceives of God or worships "in a manner which might endanger the lives of the community in which such person might live." There is no guarantee of religious liberty, reasoned the court, for fire worshippers, persons believing in human sacrifice, or persons insisting on polygamous marriages. The mother was guilty of neglecting her daughter.

In $x 948$ two Kentucky chiropractors objected to vaccination on religious grounds. ${ }^{28}$ The court noted that freedom to believe was absolute but that freedom to act was subject to restriction for social well-being. The court followed a prior exhaustive opinion, ${ }^{29}$ and stated that "the constitutional guarantee of religious freedom does not permit the practice of religious rites dangerous or detrimental to the lives, safety or health of the participants or to the public." When it was also contended that a child's health did not permit vaccination, the court responded, "The preponderance of the medical testimony is to the effect that any child physically able to attend school can be vaccinated safely and without injury."

When Drew came before the Supreme Court of New Hampshire for neglecting vaccination as prescribed for attending school, ${ }^{30}$ his objections were "partly religious and partly because he didn't want that poison injected into his child." Drew con-

\footnotetext{
${ }^{24}$ Commonwealth v. Bortlick, 5 Monroe Legal Rep. 24 (Pa. Com. Pl. I943).

${ }^{25}$ Jacobson v. Massachusetts, I97 U.S. II (1905).

${ }^{20}$ State v. Board of Education of Cincinnati, 154 Ohio St. 469,96 N.E.2d 413 (1951).

${ }^{27}$ In re Whitmore, 47 N.Y.S.2d 143, 146 (Dom. Rel. Ct. 1944).

${ }^{28}$ Mosier v. Barren County Board of Health, 308 Ky. 829, 833, 215 S.W.2d 967, 969 (1948).

${ }^{29}$ Lawson v. Commonwealth, $29 \mathrm{x} \mathrm{Ky.} \mathrm{437,} \mathrm{x64} \mathrm{S.W.2d} 972$ (1942).

${ }^{30}$ State v. Drew, 89 N.H. 54, 56, 57, r92 Atl. 629, 630 (r937).
} 
tended that he performed his duty as citizen and father when he demanded that his son be admitted unvaccinated. The court responded that it was the father's legal duty to send the boy vaccinated, and that Drew's objections to vaccination were mere opinion.

A Massachusetts statute ${ }^{31}$ required a physician's certificate indicating that vaccination would endanger the child's health, if he was to be admitted to school without vaccination. By school committee rule, the certificate had to be renewed every two months. It was contended that the words "vaccinated" and "unvaccinated" failed to distinguish immunization against smallpox from other immunizations, and that the statute was too vague to enforce. The court said that "vaccination" meant inoculation against smallpox, and held that the statutory obligation regarding school attendance involved putting children in condition to attend.

\section{F. Religious Groups Offended by Educational Materials}

In New York ${ }^{32}$ it was a school board's duty to select textbooks in English Litterature, but objection was raised to including Dickens' Oliver Twist and Shakespeare's The Merchant of Venice because they engender hatred for Jews-although it was not alleged that these books were approved because they were anti-Jewish. The board requested teachers to explain to pupils that the characters portrayed should not be looked upon as reflecting discredit on any race or religion. In upholding the selections, the court said:

Except where a book has been maliciously written for the apparent purpose of promoting and fomenting a bigoted and intolerant hatred against a particular racial or religious group, public interest in a free and democratic society does not warrant or encourage the suppression of any book at the whim of any unduly sensitive person or group of persons, merely because a character described in such book as belonging to a particular race or religion is portrayed in a derogatory or offensive manner. The necessity for the suppression of such a book must clearly depend upon the intent and motive which has actuated the author in making such a portrayal.

If it was required that "each book be free from derogatory reference to any religion, race, country, nation or personality," said the court, "endless litigation respecting many books would probably ensue." The court added:

Educational institutions are concerned with the development of free inquiry and learning. The administrative officers must be free to guide teachers and pupils toward that goal. Their discretion must not be interfered with in the absence of proof of actual malevolent intent.

A case on movie censorship from the religious standpoint, which reached the Supreme Court of the United States, ${ }^{33}$ deserves mention for two reasons: the statute

${ }^{31}$ Commonwealth v. Childs, 299 Mass. 367 , 12 N.E.2d 814 (1938). Mass. ANn. Laws c. 76, \$I5 (I953).

${ }^{32}$ Rosenberg v. Board of Education of the City of New York, Ig6 Misc. 542, 543, 92 N.Y.S.2d 344, 346 (Sup. Ct. 1949).

${ }_{33}$ Burstyn v. Wilson, 343 U.S. $495,503,504,505$ (1952), reversing 303 N.Y. 242, ror N.E.2d 665 (195I), 278 App. Div. 253, 104 N.Y.S.2d 740 (3d Dep't 195I). See N. Y. Educ. Law §122. 
required a license from the education department before showing a film, and films constitute an important avenue of education. The statutory license was to be granted unless the film was "obscene, indecent, immoral, inhuman, sacrilegious" or would otherwise corrupt morals or incite to crime. Catholics objected to showing The Miracle in a New York City theater. The review board pronounced it "sacrilegious" and denied the license. The statute was challenged as violating the First and Fourteenth Amendments to the Federal Constitution.

When it was contended that great power for evil resided in movies, the United States Supreme Court said that each mode of public expression presented unique problems of freedom and censorship, but that the basic principles of freedom applied to movies. The Court noted that the statute did not attempt to punish past offenses against freedom of expression, but required advanced permission "from state officials who judge the content of the words and pictures sought to be communicated." "Such a previous restraint," said the Court, "is a form of infringement upon freedom of expression to be especially condemned." The Court stated that when the New York court said there was "nothing mysterious" about the statute but that it simply meant "that no religion, as that word is understood by the ordinary, reasonable person, shall be treated with contempt, mockery, scorn and ridicule," the New York court was trying to apply an all-inclusive definition of "sacrilegious." This would give the censor great power, said the Court, with no guide except the pressures of powerful orthodoxies. In unanimously reversing the state court, the United States Supreme Court added:

New York cannot vest such unlimited restraining control over motion pictures in a censor. . . . Under such a standard the most careful and tolerant censor would find it virtually impossible to avoid favoring one religion over another, and he would be subject to an inevitable tendency to ban the expression of unpopular sentiments sacred to a religious minority. . . The state has no legitimate interest in protecting any or all religions from views distasteful to them which is sufficient to justify prior restraints upon the expression of these views. It is not the business of government in our nation to suppress real or imagined attacks upon a particular religious doctrine, whether they appear in publications, speeches, or motion pictures.

\section{III}

\section{Retrrement Credit for Teaching in Parochial Schools}

Retirement regulations often enable teachers to receive credit for service previously rendered elsewhere, depending on the type of school and the institution where rendered.

A 1948 Utah controversy ${ }^{34}$ concerned eligibility for retirement credit in the public school system of previous experience in parochial schools. During 1937 several parochial schools closed and turned their properties over to the state. In 1945 the retirement act was so amended that the fifty transferred teachers could count toward

${ }^{34}$ Gubler v. Utah State Teachers' Retirement Board, II3 Utah 188, I98, 201, I92 P.2d 580, 587 (r948). Utaf. Const. Art. I, $\S 4$, Art. X, $\$ 13$. 
retirement their parochial school experience prior to 1937. The amendment was challenged as violating constitutional provisions which stipulated:

No public money or property shall be appropriated for or applied to any religious worship, exercise or instruction, or for the support of any ecclesiastical establishment .... [no] school district ... shall make any appropriation to aid in the support of any school ... or other institution, controlled in whole, or in part, by any church, sect or denomination whatever.

The court held that if the legislature could consider previous experience relative to retirement, it could determine the source of that experience. Where the parochial schools were of high standard and were no longer existing, service rendered in them might be counted. However, the court warned: "If [the] church schools were still being maintained, the effect of the present act would tend to cause the teacher to leave the parochial school to become a member of a system which offered an attractive pension plan." When it was contended that considering previous experience amounted to present legislative action to increase the pay for past service, violating the state constitution, the court said the retirement benefits were intended to improve future school programs through retaining good teachers and therefore concerned payment for future service.

A New York plaintiff ${ }^{35}$ taught in a parochial school during three years of forty weeks each, with the service performed from 4:00 to 7:00 P.M. on Monday, Tuesday, Wednesday, and Thursday, and from 3:30 to 6:30.P.M. on Sunday. These were the only hours in this school devoted to non-religious instruction, and no time was devoted to recreation, music, or drawing as it was in public schools. Only 8 of the I5 weekly teaching hours came before 6:00 P.M. on week days. The teachers were licensed to teach in public schools, plaintiff's supervisor was a principal in a public school, graduates of the parochial school entered city day high schools without conditions, and retirement credit had previously been allowed for teaching in the same parochial school during the same hours. The Board of Examiners was legally responsible for evaluating experience gained outside the city system-according to a schedule allowing two years' credit for three years' outside service.

Plaintiff claimed that it was the board's ministerial duty to grant her two years' credit. The court said that evaluating experience was quasi-judicial and not ministerial - every type of experience submitted did not have to be accepted. The board ruled that plaintiff had been a part-time teacher, that the place where she taught was really not a "school" according to governing regulations, and that she was not entitled to credit. The Court of Appeals upheld the board-reversing the lower courts.

Nothing was said about the adequacy of $x_{5}$ hours per week on non-religious materials, only 8 of which came during ordinary day-school hours, for meeting compulsory school attendance requirements.

${ }^{35}$ Gimprich v. Board of Education of the City of New Pork, III N.Y.S.2d 283 (Sup. Ct. 195I), aff'd, 28I App. Div. 954, I20 N.Y.S.2d 344 (Ist Dep't I953), rev'd, 306 N.Y. 40I, II8 N.E.2d 578 (1954). 
Kussin ${ }^{36}$ sought by a summary judgment to secure two years' credit for "late afternoon" teaching in a parochial school. He taught three sessions per day of 40 minutes each over a two-year period on an annual salary-teaching after his regular day's work in the New York State Employment Service. The statute authorized credit for outside experience according to a schedule, but only for "regularly appointed" teachers serving in "day schools" on a "per annum" salary. In denying summary judgment, the court said that whether Kussin deserved credit should be determined by a full trial-inquiring into the terms of compensation, length of time and hours of service, nature of his work, and standing of the parochial school concerned. Only then could it be determined whether his request for credit should be allowed.

\section{IV}

\section{Released Time for Reurgious Teaching}

Religious instruction on a released-time basis has been a topic of considerable recent litigation. Before the well-known McCollum case ${ }^{37}$ reached the Supreme Court of the United States, cases had appeared in New York, Illinois, and California.

The Stein case $^{38}$ was governed by constitutional provisions forbidding a school district to use its property or credit to help maintain any school "wholly or in part under the control or direction of any religious denomination, or in which any denominational tenet or doctrine is taught," and by a statute providing that pupils "shall regularly attend upon instruction for the entire time during which the schools ... are in session." Upon parental consent indicated on cards, pupils were being excused 45 minutes a week for religious instruction in churches. Card stock was supplied by religious groups, but using school property and time in printing cards violated the constitution, said the court, as did diverting teachers from regular duties to check registrations, attendance, and other items.

Excusing pupils from compulsory school time to receive religious instruction also violated the statute. The statute prescribed the instruction for pupil schools, said the court, and religion is not part of it. The court added:

Consequently it would be unlawful and unauthorized for a board of education to substitute religious instruction in the school in place of the instruction required. To permit the pupils to leave the school during school hours for religious instruction would accomplish the same purpose, and would in effect substitute religious instruction for the instruction required by law.

The court further noted: "Religious instruction belongs to the parents of the children and the churches and religious organizations of the country. It should be given outside of the public schools and outside of school hours."

Two years later the Lewis case ${ }^{39}$ came before a higher New York court-with

${ }^{36}$ Kussin v. Board of Education of the City of New York, 278 App. Div. 50, ro3 N.Y.S.2d 409 (Ist Dep't I95I).

${ }^{37}$ Illinois ex rel. McCollum v. Board of Education of School District No. 71, 333 U.S. 203 (1948).

${ }^{38}$ Stein v. Brown, 125 Misc. 692, 695, 697, $21 x$ N.Y.S. 822, 826, 827-828 (Sup. Ct. 1925).

${ }^{39}$ People ex rel. Lewis v. Graves, 245 N.Y. 195, I98, 156 N.E. $66_{3}, 66_{4}$ (1927), rehearing denied, 245 N.Y. 620 , I57 N.E. 882 (I927). 
similar facts, but with a quite different judicial ruling. Children were dismissed 30 minutes a week for religious instruction at places designated by parents. A statute permitted children, otherwise in regular attendance, to be excused 30 minutes a week for outside instruction in music or dancing without violating attendance laws. "Neither the Constitution nor the law discriminates against religion" the court observed, and added that the Commissioner of Education "may make proper regulations to restrict the local authorities when the administration of the plan of week-day instruction in religion or any plan of outside instruction in lay subjects in his judgment interferes unduly with the regular work of the school." The court held that the "released-time" practice constituted no "infringement of constitutional right or abuse of statutory requirement."

In the Latimer case, ${ }^{40}$ public school personnel issued instructions, kept records, and conferred with churches on the program. Postage, telephone service, and administrative space were furnished by public schools. The constitution provided that no one shall be "required to attend or support any ministry or place of worship" and forbade legal preference for any denomination. The court said the facts and constitutional provisions were so much like those in the Lewis case that the Lewis opinion "must be held at least persuasive authority." The Latimer opinion held that the cooperation between public and church schools was too slight for it to be said that public funds were used to support religious activity, and that board authorization of the practice did no violence to the compulsory attendance law-the arrangement was reasonable and practical.

The next year the Gordon case ${ }^{41}$ arose under a California statute providing that "pupils, with the written consent of their parents, may be excused from schools to participate in religious exercises or ... instruction"; and under a constitution forbidding the use of public funds for supporting sectarian schools, teaching sectarian doctrine in public schools, or granting aid to sects or churches. Literature and cards describing the program were prepared and mailed at district expense to parents to help them indicate their desires concerning religious instruction. Pupils were transported to places of religious instruction at non-school expense, public school personnel were not in charge of pupils while "released," and the absence was not counted in computing attendance for allocating state and county school funds. Nonparticipating children remained in the school building to do such work as their teachers saw fit. The released-time practice was upheld, citing the New York and Illinois precedents.

The basic variants between the McCollum case and the Latimer and Gordon cases were that in the McCollum case religious instruction was given by church teachers in public school classrooms; these teachers were approved and supervised by the school superintendent; released pupils were required to attend religious classes,

${ }^{10}$ People $e x$ rel. Latimer v. Board of Education of City of Chicago, 394 Ill. 228, 232, 68 N.E.2d 305,309 (1946).

${ }^{41}$ Gordon v. Board of Education of City of Los Angeles, 78 Cal.App.2d $464,465,178$ P.2d ${ }_{4} 88$ (1947). 
with attendance reported to secular teachers; and non-participating pupils were required to leave their regular classrooms during the released time and pursue their secular studies elsewhere in the building. A Council on Religious Education made the arrangements. The United States Supreme Court majority held: $:^{22}$

The foregoing facts ... show the use of tax-supported property for religious instruction and the close cooperation between the school authorities and the religious council in promoting religious education. The operation of the State's compulsory education system thus assists and is integrated with the program of religious instruction carried on by separate religious sects. Pupils compelled by law to go to school for secular education are released in part from their legal duty upon the condition that they attend the religious classes. This is beyond all question a utilization of the tax-established and tax-supported public school system to aid religious groups to spread their faith. And it falls squarely under the ban of the First Amendment. ...

The Court noted ${ }^{43}$ that both majority and minority opinions in the recent Everson case ${ }^{44}$ had agreed that the Constitution provided for a "wall of separation between Church and State" and disagreed only on whether the facts involved justified applying the First Amendment. To hold, said the Court, that a state cannot use its public school system to aid any or all sects is not to hold that government is hostile toward religion.

Following the $\mathrm{McC}$ Collum decision, an abortive case arose in New York. ${ }^{45}$ The Commissioner of Education adopted regulations governing released time for instruction by "duly constituted religious bodies"-upon request by parents, given outside public school premises, with school officials maintaining attendance records for the religious classes. The court said that plaintiff "alleges no facts descriptive of the manner in which the released time programs . . . operate," and "It must be concluded ... that his contention ... is that 'Released Time' is per se unconstitutional" under the $M c$ Collum decision. The court pointed to Justice Frankfurter's statement in that case, concurred in by four other justices, indicating that some released-time programs "may be found unexceptional." If If released time is constitutional under some conditions, reasoned the state court, the New York program can be condemned only upon the finding that it aided religion. The state court upheld the programs, reasoning that the grounds for attack were speculative and uncertain.

In 1952 the Zorach case ${ }^{47}$ reached the Supreme Court of the United States. The regulations were the same as those indicated in the Lewis case. All religious instruction was at religious centers; religious organizations assumed responsibility for attendance upon such instruction; all costs were paid by religious organizations; churches reported to schools weekly on pupils released but not attending; and there was no announcement in public schools concerning the program. Pupils not released stayed in their classrooms.

333 U.S. at 209-2ro. $\quad{ }^{43}$ Id. at 2 rr.

44 Everson v. Board of Education of Ewing Township, 330 U.S. I (1947).

${ }^{45}$ Lewis v. Spaulding, I93 Misc. 66, 70, 85 N.Y.S.2d 682, 686 (Sup. Ct. I948).

1033 U.S. at 231 .

${ }^{47}$ Zorach v. Clauson, 343 U.S. 306, 311, 313, 314 (1952), affirming 303 N.Y. 161, roo N.E.2d 463 (r95I), affirming 278 App. Div. 573, ro2 N.Y.S.2d 27 (2d Dep't r951), affirming r98 Misc. 63r, 99 N.Y.S.2d 339 (Sup. Ct. I950). 
Accepting the McCollum logic, it was alleged that the weight of the public school system was behind the program, that public school teachers policed it, that the regular school program ceased while religious instruction was being given, and that without the public school as a crutch the program would be ineffective. In upholding the program, the majority of the Supreme Court said:

It takes obtuse reasoning to inject any issue of the "free exercise" of religion into the present case. No one is forced to go to the religious classroom and no religious exercise or instruction is brought to the classrooms of the public schools. A student need not take religious instruction. He is left to his own desires as to the manner or time of his religious devotions, if any.

The majority found "no evidence in the record" that the state school system coerced anybody into religious classes, but stated that "If in fact coercion were used ... a wholly different case would be presented." The majority added that the First Amendment did not require separation of church and state in all respects: if so, there could be no police or fire protection for church property or members attending services; neither could there be prayers in legislative halls, appeals to the Almighty in messages of the Chief Executive, proclamations making Thanksgiving Day a holiday, or "so help me God" in courtroom oaths; and a "fastidious atheist or agnostic" could raise other objections. "We would have to press the concept of separation of Church and State to these extremes to condemn the present law on constitutional grounds," said the Court, adding further:

We are a religious people whose institutions presuppose a Supreme Being. We guarantee the freedom to worship as one chooses. ... When the state ... cooperates with religious authorities by adjusting the schedule of public events to sectarian needs, it follows the best of our traditions. For it then respects the religious nature of our people and accommodates the public service to their spiritual needs. To hold that it may not would be to find in the Constitution a requirement that the government show a callous indifference to religious groups. That would be preferring those who believe in no religion over whose who do believe.... It [the state] may not coerce anyone to attend church, to observe a religious holiday, or to take religious instruction. But it can close its doors or suspend its operations as to those who want to repair to their religious sanctuary for worship or instruction.

Justices Black, Frankfurter, and Jackson did not think it took "obtuse reasoning" to inject the "free exercise of religion" issue into the case. Each wrote a dissentall three maintaining that the majority overlooked or minimized the main issue: using compulsory attendance machinery to recruit pupils for religious instruction. At one point Black said: ${ }^{48}$

Here the sole question is whether New York can use its compulsory education laws to help religious sects get attendants presumably too unenthusiastic to go unless moved to do so by the pressure of this state machinery. That this is the plan, purpose, design and consequences of the New York program cannot be denied. The state thus makes religious sects beneficiaries of its power to compel children to attend secular schools. ... New York

${ }^{4} 343$ U.S. at 3 I 8. 
is manipulating its compulsory education laws to help religious sects get pupils. This is not separation but combination of church and state.

At another point he added $:^{49}$

Before today, our judicial opinions have refrained from drawing invidious distinctions between those who believe in no religion and those who do believe. The First Amendment has lost much if the religious follower and the atheist are no longer to be judicially regarded as entitled to equal justice under law.

Justice Frankfurter said appellants should have been allowed to show coercionsuch a showing was ruled out by the lower court as irrelevant, and the point ignored by the Supreme Court because the record showed "no evidence of coercion." He also noted: $:^{50}$

The unwillingness of the promoters of this movement to dispense with such use of the public schools betrays a surprising want of confidence in the inherent power of the various faiths to draw children to outside sectarian classes-an attitude that hardly reflects the faith of the greatest religious spirits.

Justice Jackson sensed two essentials in the plan: the state compels pupils to yield a large amount of time for secular education, then releases part of it if they take religious instruction. Jackson said that if the school day was too long, it could be shortened for all pupils-with those desiring religious instruction going where they could get it, and others going elsewhere. Under such freedom, however, the truant officer would not bring pupils to religious classes. Jackson further noted: ${ }^{61}$

The same epithetical jurisprudence used by the Court today to beat down those who oppose pressuring children into some religion can devise as good epithets tomorrow against those who object to pressuring them into a favored religion. And, after all, if we concede to the State power and wisdom to single out "duly constituted religious" bodies as exclusive alternatives for compulsory secular education, it would be logical to also uphold the power and wisdom to choose the true faith among those "duly constituted." We start down a rough road when we begin to mix compulsory public education with compulsory godliness.

\section{V}

\section{Public Funds for Parochial Schools}

Several cases have involved the use of public funds for religious groups-more directly than cases heretofore reviewed.

\section{A. Transportation of Pupils to Parochial Schools}

In 1943 the author included cases on this subject, which had come before the nation's higher state and federal courts up to that time, in an analysis of decisions on transportation issues in general..$^{52}$ More cases on the subject have arisen since that time than can be appropriately considered here..$^{53}$

\footnotetext{
10343 U.S. at 320 .

343 U.S. at 325 .

${ }^{50} 343$ U.S. at 323.

52 Law and Liability in Pupil Transportation 34-45 (University of Chicago Press, I943).

${ }^{\longleftarrow 3}$ See Bolmeier, Legal Issues in Pupil Transportation, supra, pp. 45-59.
} 
B. Free Textbooks for Parochial School Pupils

It is nearly a quarter century since Chief Justice Hughes spoke for the Supreme Court of the United States, defending the "child benefit" theory in upholding a Louisiana practice of supplying textbooks at public expense to pupils in parochial schools. $^{\text {.4 }}$ However, our state constitutions and statutes vary considerably in provisions governing the selection and distribution of such books and instructional materials. ${ }^{\text {.5 }}$

In I922 a special statute authorized Ogdenburg, New York, upon proper vote, to furnish "free textbooks and ordinary school supplies for the use of the pupils of the school district of said city," and provided that these materials "shall remain the property of the board of education." The controversy related to supplying books to Catholic parochial schools.

The court said that the schools covered by the act "are the public schools of the district under the control of the board of education"-Tregardless of what other schools might exist within the territorial limits of the district. The court added: ... there is nothing which implies that the books and supplies are to be furnished to the pupils as distinguished from the school. . . . The school is not the building and its equipment. ... It is the institution, and the teachers and scholars together, that make it up. The pupils are a part of the school. ... It seems to us to be giving a strained and unusual meaning to words if we hold that the books and the ordinary school supplies, when furnished for the use of pupils, is a furnishing to the pupils, and not a furnishing in aid or maintenance of a school of learning. It seems very plain that such furnishing is at least indirectly in aid of the institution, and that, if not in actual violation of the words, it is in violation of the true intent and meaning, of the Constitution, and in consequence equally unconstitutional.

Under a slightly different legal framework, the Supreme Court of Louisiana ${ }^{57}$ in I929 reached an essentially opposite conclusion. The state constitution assured freedom of worship; prohibited using public money to support a church, religious denomination, priest, minister, or teacher of religion; forbade devoting public funds to a private or sectarian school; and prohibited lending public "things of value" to any person or corporation. A statute authorized tax funds for "supplying school books to the school children of the State," "free of cost to such children." Books were being supplied to children in parochial schools, and it was contended that to do so was using public funds to support sectarian schools. In upholding the practice, the court said-in a 4-to-3 decision:

In our opinion .... these acts violate none of the foregoing constitutional provisions. One may scan the acts in vain to ascertain where any money is appropriated for the purchase of school books for the use of any church, private, sectarian, or even public

\footnotetext{
Ec Cochran v. Louisiana State Board of Education, 28I U.S. 370 (1930).

${ }^{t}$ See Bolmeier, What the Courts Say About Church and Public School Relationships, in LEE O. Garber, The Yearbook of School LaW, 1953, 88-9r.

${ }^{50}$ Smith v. Donahue, 202 App. Div. 656, 662, 663, 664, 195 N.Y.S. 715, 720, 721, 722 (3d Dep't

${ }^{87}$ Borden v. Louisiana State Board of Education, 168 La. 1005, 1019, 1022, 123 So. 655, 660-66x (1929). La. Rev. Stat. $\$ 17: 351-352$ (1950).
} 1922). 
school. The appropriations were made for the specific purpose of purchasing school books for the use of the school children of the state, free of cost to them. It was for their benefit and the resulting benefit to the state that the appropriations were made. True, these children attend some school, public or private, the latter, sectarian or non sectarian, and that the books are to be furnished them for their use, free of cost, whichever they attend. The schools, however, are not the beneficiaries of these appropriations. They obtain nothing from them, nor are they relieved of a single obligation, because of them. The school children and the state alone are the beneficiaries.

The court noted that some of these schools teach religion, but that nothing in the act implied that any of the books concerned were religious books-they were the same books as were supplied to children attending public schools. The court added:

While it is true that there is a lending here of things of value, belonging to the state, still this lending is not the lending prohibited by the Constitution. The lending there contemplated is a lending not connected with the reasonable exercise of the police power. Where the ... lending ... is necessary in the reasonable exercise of the police power ... the Constitution was not intended to prevent the . . . lending. Were it otherwise, the state . . . could not furnish, for instance, vaccine for the prevention of an epidemic. . . . The furnishing of school books ... tends directly to promote the education of the children ... thereby improving morals of the children and promoting the general welfare and safety of the people, and hence comes within the police power.

The next year another Louisiana case arose over the same issues, ${ }^{58}$ and reached the Supreme Court of the United States. The main contention on appeal did not seem to relate directly to the religious issue but to the matter of distributing books to pupils in private and parochial schools as taking property for a private use in violation of the Fourteenth Amendment. In upholding the practice, the Court quoted the above language from the Borden case, and then said:

Viewing the statute as having the effect thus attributed to it, we cannot doubt that the taxing power of the state is exerted for a public purpose. The legislation does not segregate private schools, or their pupils, as its beneficiaries or attempt to interfere with any matters of exclusively private concern. Its interest is education, broadly; its method, comprehensive. Individual interests are aided only as the common interest is safeguarded.

A I94 Mississippi case" involved a constitutional stipulation that "No religious ... sect . . . shall ever control any part of the school or other educational funds . . . nor shall any funds be appropriated toward the support of any sectarian school. ..." A special board was empowered by statute "to select, purchase, and distribute free textbooks by loaning same to the pupils," and the statute specifically stated that the books were to be distributed to pupils in the free public elementary schools, "and all other elementary schools located in the state" which met standards set by the State Department of Education.

Although Louisiana made no provision comparable to that in Mississippi con-

${ }^{88}$ Cochran v. Louisiana State Board of Education, $28 \mathrm{r}$ U.S. 370, 375 (1930), affirming, I68 La. I030, I23 So. 664 (1929).

${ }^{69}$ Chance v. Mississippi State Textbook Rating and Purchasing Board, 100 Miss. 453, 462, 472, 200 So. $706,7 \mathrm{r}_{2}$ (r94I). 
cerning "all other elementary schools," the majority of the Mississippi court said, regarding the Borden Louisiana case: "The constitution and statutory provisions are for all practical purposes identical with ours." The Mississippi court followed the Borden decision and upheld the constitutionality of the Mississippi statutes.

Two years later a case arose under a South Dakota statute ${ }^{60}$ resembling that in the New York case (note 56 , supra). The board of any independent district maintaining a four-year high school was authorized to "adopt and purchase all textbooks for any such independent district . . . and furnish the same to the pupils of such district free . . . such textbooks may be paid for from the school funds of such district." Haas contended that "pupils of such district" meant all pupils residing in the district regardless of school attended, and demanded books for pupils of the Sacred Heart parochial school.

The court said that the quoted section must be interpreted with other parts of the statutes on public schools, and so interpreted "district" meant school district and not a general region or territory. The court noted that if "school corporation" is substituted for "district," and the phrase becomes "pupils of such school corporation," any geographical confusion is clarified; and, further, that the statute referred to the Board of Education "of any independent district maintaining a four-year high school." The statute did not "empower or require public school corporations to furnish text-books either to pupils of private, sectarian, or parochial schools or to any other person not actually enrolled in and in attendance upon some school maintained as a part of the public school system of this state."

\section{License-free Bus for Church School}

A Church of the Nazarene in Ohio conducted weekly Sunday school, other functions during the week, and a summer vacation Bible school. ${ }^{61}$ It operated a motor bus "solely to transport school children to and from Sunday school, school functions and the vacation Bible school," and sought to compel the state registrar of motor vehicles to issue a license without cost.

The statute exempted school buses from the license tax, and defined school bus to mean "any vehicle, however owned, used exclusively to transport school children, either to and/or from school, or to and/or from any school function, having a seating capacity of more than five persons exclusive of the driver." The court said "school" when standing alone means "an institution conducting a course of general education and mental training similar to that offered to children by a public educational system," whereas "Sunday school" and "Bible school" applied to places of religious instruction operated by churches. Mandamus to issue the license plates free was denied.

\footnotetext{
${ }^{00}$ Haas v. Independent School District, 69 S.D. 303, 307, 310, 9 N.W.2d 707, 710 (1943). See S.D. CODE $\$ 15.1706$ (1939).

${ }^{81}$ State v. Fogo, 150 Ohio St. $45,46-47,79$ N.E.2d 546, 547 (1948), affirming, 79 N.E.2d 9 r4 (1948). See OHo Gen. Code \$6295-I (1945).
} 
Taking Over by Churches of Public Schools and Revenues ${ }^{32}$

Sometimes relationships between churches and public schools practically amount to churches taking over public schools and revenues. Two such cases arose in Missouri-twelve years apart.

The 1953 decision $^{63}$ concerned practices in Krakow, Gildehaus and Ziegenmeyer primary schools, operated by Reorganized School District 8. Until r93I these schools were operated as parochial schools. Thereafter certain parochial school buildings were used, although legal title to the buildings remained in the Archbishop of St. Louis -held for the Catholic church. Districts paid no rent at Krakow and Gildehaus, but $\$ 150.00$ per year at Zeigenmeyer. Since $193 \mathrm{I}$ nuns from the Poor School Sisters of Notre Dame taught at Krakow and nuns from the Sisters of the Adoration of the Most Precious Blood of O'Fallon taught at Gildehaus-with no lay teachers. Since Ziegenmeyer was a one-teacher school, and the religious order forbade a nun to live alone, this school was taught by a Catholic lay-woman. Nuns who taught at Krakow lived in the school building, about $15^{\circ}$ yards from church. The Gildehaus school was on the same tract as the priest's home, nuns' house, and church. There were no religious symbols on or in the school buildings, except a cross on the Gildehaus school comparable to that on the nearby church.

No religious books, pamphlets, or pictures were distributed at school, and in I93I religious instruction in classrooms was discontinued. However, the nuns always wore religious garb in classrooms, and pupils addressed them by religious rather than legal names. They taught for lower salaries than lay teachers of comparable qualifications, and most of their earnings went to the church. District 8 never refused to employ a nun assigned by the Mother Superior. Vows of the Notre Dame Sisters provided: "Every day teaching sisters are in duty bound to bring to the place appointed by the Superior any money they may have received. ... . The time of a sister belongs to the order." Vows of the Precious Blood Sisters were comparable. Church law (Canon 499) stipulated: "All members of religious orders are subject to the Roman Pontiff as their supreme superior to whom they owe obedience, also by virtue of their vows of obedience."

Krakow and Gildehaus pupils regularly attended mass in adjoining churches at 8:00 A.M., received religious instruction from 8:30 to 8:50, then returned to the school buildings. Nuns who taught in the schools also gave the religious instruction. Non-Catholic children waited around the schoolhouse and grounds until 9:00. Catholic children from the nearby Rock Hill District, which maintained no school, were sent to District 8 with tuition paid by Rock Hill, whereas non-Catholic children from Rock Hill attended school elsewhere. Children of District 8 who objected to Krakow and Gildehaus practices were sent to schools elsewhere, with tuition paid

${ }^{62}$ Certain cases on this subject were reviewed by the author earlier: sec Communitr UsEs OF Public Schoor. Facilities 67-7I (Columbia University, King's Crown Press, 1951).

${ }^{63}$ Berghorn v. Reorganized School District No. 8, 260 S.W.2d 573, 579, 583-584 (Mo. Sup. Ct. 1953), rehearing or transfer to coutrt en bane denied. 
by the district. The same school buses and drivers brought children to school on school days and to church for religious training on Saturdays-with bus expenses apportioned between church and district. Among other facts considered by the court were canons stipulating that "Catholic children are to be educated in schools where not only nothing contrary to Catholic faith and morals is taught, but rather in schools where religion and moral training occupy first place," and that "Catholic children shall not attend non-Catholic, indifferent schools that are mixed, that is to say, schools open to Catholic and non-Catholic alike," without church permission.

The practices were attacked as contrary to constitutional and statutory provisions for maintaining free public schools apart from sectarian influence and religious activity.

The trial court found that the nuns

by their oaths cease to exist as free citizens and as individual economic units, and during their service execute contracts, receive and pay out money in taxes only in a nominal perfunctory and formal sense, while in reality, acting as instruments and agents of their religious orders, engage in executing the policies of the Roman Catholic Church; that by the very nature of their obligations and of the control to which they submit themselves, the final and absolute control of the secular or sectarian existence and personal actions of the nuns ... is vested in the Church authorities; that because of the character of their obligations said nuns are disqualified from teaching in any public school in the State of Missouri. ... .

The trial court found that in case of conflict between church and school authorities the nuns would be obligated to obey orders from the church hierarchy.

Regarding the Gildehaus and Krakow schools, the trial court found certain aspects of their operation "destroyed the free public character of said schools and rendered them ineligible for support from public funds or by public authority." The trial court added:

That the policy of the Roman Catholic Church to intermingle education and religious teachings in order to secure and strengthen the faith of its adherents and to secure indoctrination of children in its religious principles is in direct conflict with the policy of the State of Missouri in the fields of public education and of the free public schools; that the educational policies of the State of Missouri, as expressed in its constitution and laws, and the educational policies of the Roman Catholic Church cannot be effectuated in any single school at the same time; that said policies are utterly inconsistent and mutually exclusive.

The trial court restrained District 8 from using public money for joint operation of buses or for supporting the present Krakow and Gildehaus schools; from employing any person wearing a garb prescribed by a religious order of the Catholic Church; and from conducting any school on church property unless "removed and separated" from premises on which church buildings, nuns' homes, and priest's homes are located and on premises which are validly leased and free from church control during the lease period. Rock Hill could not pay tuition for children attending Gildehaus and Krakow. 
A division of the state supreme court affirmed the trial court on all these matters.

In I94I the St. Cecelia school at Meta in Missouri was being conducted in a building adjoining a Catholic Church. ${ }^{64}$ There were two school rooms on the first floor, and one room plus a chapel on the second. The three rooms were rented by the school board. About ten years before the suit, the school adopted the state course of study and textbooks, and was thereafter supported by public funds. However, many parochial school features remained. The school was taught by Sisters of the Most Precious Blood-wearing religious garb while teaching, and paid by the board. Religious pictures and symbols hung in the schoolroom, with fonts of holy water by the door. An inferior school was maintained for Protestant children, with Catholic children ordered by the board to attend St. Cecelia. Regarding St. Cecelia's program, the court said:

We find the usual school day commencing with prayer in the morning. After prayer the pupils are marched, one room at a time, to the Catholic church next door for Holy Mass. After Mass the pupils are marched back to their school rooms where they receive religious instruction. In this they study the Catholic catechism and the child's Catholic Bible. On one or two days of each week the parish priest gives religious instruction to the pupils in the mid-morning, either at the church or in the schoolhouse chapel. On Friday afternoons the pupils are again marched to the church for confession. In the quarterly "Teacher's Report to the Parents" the subject "Religion" is included under "Branches Pursued" and a grade in this subject is given to each pupil.

Harmony prevailed until the Meta district was consolidated with another district, whereupon conflict arose between two Catholic factions.

The state constitution provided for freedom of worship, and forbade the use of public funds for any sectarian purpose or the support of any sectarian teacher. The court said that the fact that Mass was ordinarily before school hours and that nonCatholic children might be excused did not make the procedure lawful, particularly when all children arrive and leave on the same school buses. The court noted that since the statute gave school boards part of the earlier common-law rights of parents to control their children, it was necessary for boards to follow the statute in any conflict with parents over controlling children. The court added that the board could not

enforce religious worship by children even in the faith of their parents. Furthermore, the segregation of the Catholic from the non-Catholic children and their mandatory attendance at one or the other of the two grade schools according to their religion, whether the schools be of equal or of unequal facilities, likewise constitutes a denial of complete religious freedom.

In holding that St. Cecelia was a church school-in spite of nominal board supervision-and that the use of public funds to support it violated the constitution, the court said:

If the management of this school were approved, we might next have some other church gaining control of a school board and have its pastor and teachers introduced to

${ }^{84}$ Harfst v. Hoegen, 349 Mo. 808, 811, 815, 817, 163 S.W.2d 609, 610, 613, 614 (194r). 
teach its sectarian religion. Our schools would soon become the centers of local political battles which would be dangerous to the peace of society where there must be equal religious rights to all and special religious privileges to none.

The extent, if any, to which the practices in the 1953 case were influenced by those noted in the I94I case, is not indicated in the I953 opinion-although the I94I case is cited.

In I945 an indecisive case arose in Connecticut. ${ }^{65}$ Since 1879 , New Haven had maintained a school in a Catholic orphanage. At the time of suit the city also maintained schools at another orphanage, a hospital, and a museum owned by Yale University. The Catholic building was shared by the school, a chapel, an office of priests, living quarters for nuns and priests, and living quarters for orphanage inmates who attended the school. Inmates prayed upon arising, and also before and after meals, and attended Mass on Sundays and religious holidays. Before the school session each day, inmates had religious instruction by a nun, but no such instruction during school sessions. The teaching staff consisted of two lay women and eight nuns-all certified public school teachers appointed by the city school superintendent and paid from public funds. Textbooks, medical services, diplomas, course of study, and teacher retirement provisions were the same for this school as for other city schools.

In holding that the school was a public school, the court said that the facts that all children were Catholic-when the school was "open" to non-Catholics-and that religious exercises were held in the schoolroom before the school session-when attendance at these exercises was not compulsory-did not make it a parochial school. As to whether wearing religious garb in classrooms constituted religious influence, the court said that the only conclusion to draw from the conflicting cases was that it was a matter for the trial court to decide.

A dissent emphasized two points. ${ }^{66}$ It cited considerable authority that religious garb worn in classrooms was itself a religious influence-children learn by seeing as well as by hearing. It also noted that during the four years chiefly in controversy an average of 370 pupils attended the school, "every one of whom was a Catholic and an inmate of the orphanage." Under these conditions, to say that the school "always has been open to any child living in the neighborhood regardless of religious faith," as showing the nonsectarian character of the school, was "to substitute theory for reality."

A "wholesale" approach to the Missouri problem faced the Supreme Court of New Mexico ${ }^{67}$ in I95 1 -involving I2 Catholic parochial schools, and ${ }_{13}$ schools called "public" but run largely as if parochial. In schools of both groups nuns and brothers -called the "Religious"-were paid from public funds, wore religious garb while teaching, and gave religious instruction during school hours. Textbooks and transportation, paid for from tax funds, were furnished for both groups. There was

${ }^{85}$ City of New Haven v. Town of Torrington, I32 Conn. I94, 43 A.2d 455 (r945).

"132 Conn. at 206, 43 A.2d at $460-461$.

${ }^{87}$ Zellers v. Huff, 55 N.M. 50I, 510, 51I, 521, 526, 236 P.2d 949, 954, 955, 962, 965 (195I). 
variation within the second group about using church-owned buildings, teaching prayers during school hours, distributing church literature in school, releasing pupils from school for Mass and confessionals, and having religious pictures in schoolrooms. One county school board contracted with the Mother Superior of a Church Order to employ sisters for five years or more, "which contract was approved by the Archbishop of the Catholic Church in St. Louis, Missouri." In at least one school of this group, church brothers refused to teach girl students-necessitating additional teachers at public expense. Bus schedules were adjusted to provide for religious instruction. Non-Catholic children were required to attend religious instruction during inclement weather and to hear Catholic prayers at all times. The State Board of Education adopted a separate line of textbooks for the Catholic schools, but furnished them free to schools of both groups. The Religious who taught in "public" schools were assigned by heads of Church Orders and usually accepted by school boards without question. In only one instance within the second group did the board try to exercise its legal authority on the subject-requesting of the Mother Superior that the principal be not returned and that two Sisters scheduled for transfer be retained. The Mother Superior said the charges against the principal were trivial, and she "would not have her Sisters shoved around." The objectionable Sister was returned as principal and the other two were transferred.

After summarizing facts from 2,200 pages of materials submitted, the court said: "In short, New Mexico had a Roman Catholic school system supported by public funds within its public school system."

The arrangement described came to a showdown in Dixon where Catholics and Protestants were about equal in number. Protestants objected to holding public school in Catholic church property where nuns taught both church and secular curriculums, but were told by the county board that there were no funds for a public school building. Protestants then donated money and labor to construct a building, gave it to the county, and requested that it be staffed by lay teachers. The request was denied, a Sister was made principal, and sectarian teaching continued. A Protestant committee then went to the county board, demanding that sectarian teaching at Dixon be stopped. The county board said it had no jurisdiction and referred the committee to the State Board of Education. The state board said it had no written appeal and could no nothing. The committee offered to tender proof to support its protest, but the offer was summarily turned down-after objection by an attorney who subsequently represented the Religious at the trial. After a "warm" meeting with the committee, the state board had a session with the Archbishop of Santa Fe. Thereupon the state board, "in an earnest effort to solve the community school problems of Dixon" recommended and insisted on the following plan: that the new Dixon school employ a lay principal and teachers and teach grades $\mathrm{I}-6$, that the public school taught by Catholic Sisters teach grades 7-12, that buses bringing children to the Dixon school be scheduled to arrive in time 
for schopl "but not necessarily earlier," and that no religious instruction be given in either school on school days.

The Archbishop sent a letter to all Religious teaching within the Archdiocese of Santa $\mathrm{Fe}$, which read in part as follows:

In view of the present agitation against Sisters in Public Schools and to avert grave future difficulties that could prove disastrous to the continuation of Sisters in public schools in the State of New Mexico, I request that no religious instructions be given in public school buildings by the teachers on school days. Catechism should be taught on Saturdays and Sundays.

School buses bringing children to school will run on a schedule that will bring the children to school in time, but not necessarily earlier, and will leave immediately after school.

Along with the foregoing letter, the Religious of Dixon received a special letter advising the removal of religious emblems from public school rooms, forbidding religious instruction and prayers on school days, and stating that if Sisters did not follow these orders their removal from the Dixon school would be effected.

The court noted that in all cases except Dixon it was the Archbishop who stopped religious instruction by nuns and brothers in the public schools, not the State Board of Education which was legally bound to do so. The court also noted the Archbishop's letter directing bus schedules as well as instruction.

The state constitution provided for freedom of worship and forbade the state to show any religious preference. It also provided for "a uniform system of free public schools" open to all children, which schools should "forever remain under the exclusive control of the state," and that no public funds should be used for any sectarian school and no pupil be required to attend religious service.

Section 55-r I02 of the New Mexico statutes ${ }^{68}$ reads:

No teacher shall use any sectarian or denominational books in the schools or teach sectarian doctrine in the schools, and any teacher violating the provisions of this section shall be immediately discharged, his certificate to teach school revoked, and be forever barred from receiving any school moneys and employment in the public schools in the state. Provided, that this section shall not be construed to interfere with the use of school buildings for other purposes authorized by the county board after school hours.

The lower court, among other things, forever barred I39 Religious from receiving any school money or future employment in the public schools of New Mexico, and forbade public school officials to rent or otherwise acquire space for public school use in buildings over which they did not have absolute control.

Before the case reached the state supreme court some ills were remedied, and the Religious urged that the basis of complaint was removed. That court recognized that the State Board of Education and the Archbishop had changed their policies, but said that in the absence of an official court declaration these policies might change back-and proceeded to a decision on the merits.

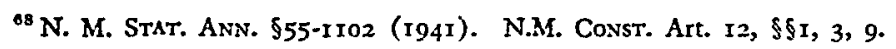


The court cited church canons and testimony of the Religious showing that these teachers were bound to obey their religious superiors, said that they were obeying church dictates in violating the constitution and statutes of New Mexico, and added: "The question is are they so bound in their consciences and by the laws of their church that they cannot serve as teachers in the public schools and perform their duties in accordance with the federal and our state constitutions." The court also stated: "For the position or policy of the Roman Catholic Church as to schools, we have no better information than that given by Mr. Justice Jackson" in his dissent to the Everson decision.9 Jackson said we know that these church schools "are parochial only in name-they, in fact, represent a world-wide and age-old policy of the Roman Catholic Church." The New Mexico court then included Jackson's quotation of canon law to the effect that Catholic children should be educated only in schools in which Catholic faith and morals are given first place, that children in every elementary school should be instructed in Christian doctrine, that high school students should acquire a deeper religious knowledge from priests who are selected by the bishop, that religious teaching in any school should be subject to the authority and inspection of the church, and that local Ordinaries should have the right to approve books on Christian doctrine or to remove teachers and books.

The New Mexico court held that membership in a religious order did not disqualify persons as public school teachers, and that payment of one's salary into the church treasury did not constitute public support of a church. However, the wearing of religious garb and insignia while teaching in a public school constituted religious influence and had to be stopped. Teaching of religious doctrine and dissemination of religious literature in public schools also had to stop.

When it was contended that the religious instruction was not given during the school day but either before or after regular school hours, and that the statute was penal and required strict construction, the court said:

The practices prevailing in each of the schools. where religion was taught were so uniform that we must conclude they were a part of a general plan and design to circumvent the constitutional and statutory provisions prohibiting the teaching of sectarian religion in the public schools. The Religious are intelligent people and the course they pursued proves they were aware of the laws on the subject and the penalty. Neither are we impressed by the facts that county boards of education encouraged such practices and that members of the State Board of Education and other public officials charged with the enforcement of our laws ignored and even encouraged the violations. Nor does the fact that such violations have continued for a long period of time justify us in refusing to give effect to a statutory penalty passed in aid of applicable constitutional provisions. Constitutional and statutory, provisions are not amended or repealed by the failure of officials to enforce them.... The Religious by their actions having made the thirty minute period a part of the regular-school day and had the buses operate in cooperation with such plan, and, in addition, utilizing the compulsory school attendance law, cannot be heard to say they were holding such religious classes only before or after school hours.

${ }^{69}$ Everson v. Board of Education, 330 U.S. I, 22-23 (1947). 
The penalty stipulated in Section 55-r102 was not void because of vagueness; nor did the discharge of these teachers through court action deprive them of tenure rights concerning notice, hearing on written charges, right of appeal, or salary pending a hearing.

The court concluded that furnishing an indoctrination set of textbooks for tax supported schools violated a constitutional provision for public schools which are free from sectarian control; furnishing free textbooks of any kind to pupils in notax supported schools violated provisions forbidding school districts to make donations to persons or corporations; and furnishing free transportation to pupils of parochial schools violated provisions that no funds appropriated, levied, or collected for educational purposes shall be used to support a sectarian school, and provisions that no teacher or pupil shall be required to attend religious service.

The court found the evidence against 8 of the I39 Religious insufficient for conviction. In these doubtful cases the teaching licenses were not revoked and the persons were not forbidden forever to be again employed to teach in the public schools of New Mexico. The constitutionality of Section 55-1102 was not questioned.

\section{VII}

\section{Conceusions}

Certain concluding observations seem justified.

A. Legal controversies on religious issues in public schools are not confined to any denominational group, but have concerned several Christian sects as well as nonChristians. Some sects have been involved more often than others. For example, flag saluting has usually involved Jehovah's Witnesses, but distribution of religious literature through public schools has involved different sects-as have "released-time" programs. Disputes over wearing religious garb in classrooms have usually involved Catholics.

B. For many Americans, sectarianism implies different Christian groups. Sometimes Jews are included. As our nation assumes more leadership in international politics and culture, our thinking on religious matters should consider various nonChristian groups.

C. Certain areas of adjudication seem helpful in observing the judicial process. For example, some "released time" opinions talk about who printed the cards signed by parents, time spent by public school teachers in registering students for religious classes, and other trivia-as if straining at a gnat for thoroughness. But it was not until the $M c$ Collum case (supra note 37 ) reached the Supreme Court of the United States that significant attention was given to using compulsory attendance machinery to secure pupils for religious classes-the most basic issue involved in these cases. Thereafter the majority in the Zorach case (supra note 47 ) essentially by-passed the issue-although the dissenters placed it in perspective. It now looks as if another decision is needed, focusing on compulsory-attendance machinery. The "released- 
time" cases show how long our higher courts sometimes wander around before getting down to fundamentals.

D. The Berghorn and Harfst (supra notes 63 and 64) cases suggest possibilities whereby an extensive and well-organized religious body might, for its private benefit, drain the public treasury through the public school system. The basic facts were much the same in both cases, concerning prayers, Mass, use of church property, teaching by sisters of the "Most Precious Blood," wearing religious garb in the classroom, allocating Catholic and non-Catholic children to different schools, and other items. Several practices which the state supreme court in 194r said must be stopped in Meta (Harfst case), came before the court in 1953 as practices in Krakow and Gildehaus (Berghorn case). To assume that members of the "Most Precious Blood" group in one community in 1953 knew nothing about the experience of the "Most Precious Blood" group in the other community in I94I, two Missouri communities both organized from the church standpoint under the Archdiocese of St. Louis and lying about 80 miles apart by highway or by railroad, would be to attribute low intelligence or organizational anarchy to the groups concerned. The case materials do not indicate that such characteristics should be so attributed.

E. For several reasons the Zellers case (supra note 67) from New Mexico deserves mention-the large number of parochial as well as "pseudo-public" schools involved, the scope of controls and activities taken over by the church in practices which violated constitutional and statutory provisions regarding public schools, the extent to which duly chosen public officials neglected and refused to perform their legal duties, the uniformity of practice among the different communities concerned -suggesting an over-all plan and supervision-the role of the Archbishop of St. Louis-reminiscent of the Missouri situation-and the existence of penal provisions in the statute intended to discourage violations. Whether the Zellers case represents an organized effort by a church to see how far it could invade and take over the public school system before somebody called a halt, as the court implied, may be decided by the reader from the evidence. However, one court statement is significant: "In short, New Mexico had a Roman Catholic school system supported by public funds within its public school system."

F. These Missouri and New Mexico cases make it clear that if constitutional and statutory provisions are to be effective in keeping sectarianism out of public schools and preventing the use of public funds for religious purposes, those provisions must include penalties for offenders-not merely authority to stop the practice in the instance that is before the court. If court authority is limited to stopping practices in particular suits, the courts could be kept busy with case after case of essentially the same type-as an organized group shifts from one separate and somewhat isolated school corporation to another, in its versatile and mobile attack on the public schools. This could resemble trying to head off communism, wherever it might choose to strike. 
The New Mexico statute included limited penal provisions-and some I3I religious sisters and brothers were forever barred from receiving public school money or from future employment in the state's public schools. However, no penalty was provided, regarding persons or property, for the architects of the over-all plan to which the court referred - or for the organization to which these dedicated brothers and sisters owed their highest allegiance, and whose objectives they were pursuing as they violated the state's constitution and statutes. In this as in other aspects of social regulation and adjudication, the tools which are used on a particular job may have less long range importance than the planners and tool designers.

A note should be added on the I3I Religious who were barred so far as New Mexico is concerned. This would not prevent a nation-wide church organization from transferring them elsewhere-as a body or in small units, somewhat as the army might transfer a company of infantry from place to place-as a body or in smaller units. In new communities the members of the religious groups could incorporate the results of earlier experience. Federal regulations prohibit the transfer of some types of persons across state lines, but certainly the American people have not thought of any such regulation concerning school teachers or members of religious orders. The New Mexico case is another instance of the importance in the American conception of democracy of alertness and moral integrity on the part of officials in local units of government.

G. Retirement credit for teaching in parochial schools is a recent area of dispute. With a shortage of qualified teachers, boards may show little concern for retirement commitments. If public schools allow generous credit to teachers transferring from parochial schools, the public schools could "inherit" a substantial retirement burden through the transfer of old teachers who are in pre-retirement status. This prospect would be affected by the number and size of local parochial schools, and by the personnel policies of both public and parochial schools.

$\mathrm{H}$. It is sometimes stated that although a court permitted a particular "religious" activity in a certain case, the principle of "separation of church and state" was unimpeachably maintained. Such statements of abstraction can soothe audiences into accepting theory for reality - witness the use of democratic terminology and concepts by Hitler, Stalin, and Franco, as they progressively undermined and eliminated any democratic practices which their peoples inherited from earlier regimes. It is basic to remember that general principles have reality only in specific applications. There might be theoretical agreement on a "wall of separation" but dispute on what the wall separates. It is strictly fiction to assume that a country can hold a general principle intact on one hand, and permit local practices which erode it on the other.

I. It has been urged that aiding all religious groups is not showing favoritism to any one group. As Justice Jackson noted in his Zorach dissent (supra note 5I), aiding all such groups is favoring religious over non-religious groups-partly by tending to force everybody into some religious camp-whereas the Federal Constitution prescribes that in law all groups be treated equally. Moreover "aiding all re- 
ligious groups" is really aiding primarily the strongest among them. Justice Frankfurter noted in the $M c$ Collum case ${ }^{70}$ that there probably were sects in the community concerned which were not strong enough to provide special religious instruction for their children on a "released-time" basis. Released time "disfavors" these children. Furthermore, the only denominations which profit from transporting children to parochial schools at public expense are those which are strong enough to maintain numerous parochial schools. Much the same applies to free textbooks. "Where there is true religious faith, that which should be rendered unto God ought not need to be designated and collected by Caesar."

${ }^{70} 333$ U.S. at 212-232. 